\title{
Effect of Ionizing Radiation on the Redox Chemistry of Penta- and Hexavalent Americium
}

Gregory P. Horne, Travis S. Grimes, William F. Bauer, Christopher J. Dares, Simon M. Pimblott, Stephen P. Mezyk, and Bruce J. Mincher.

UV-Vis Spectra

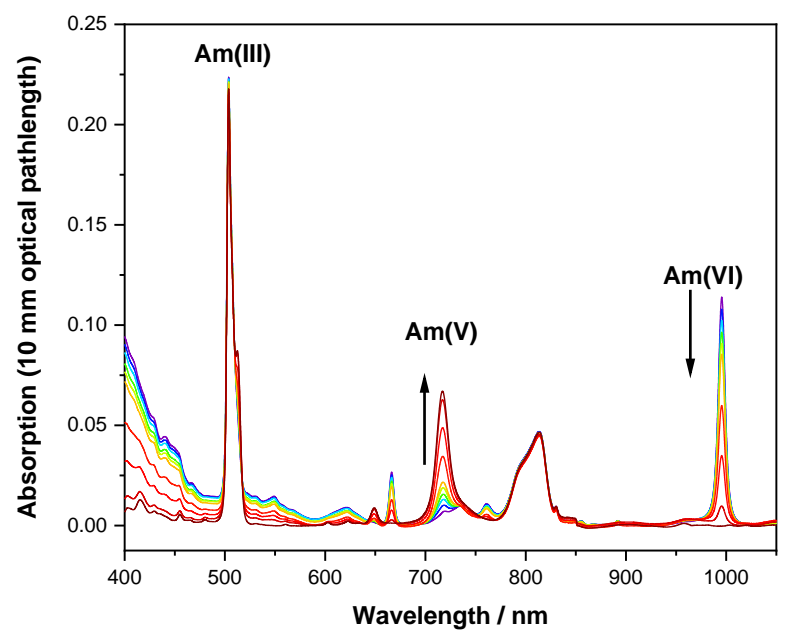

Figure S1. Complimentary UV-Vis absorption spectra for manuscript Figure 2 - gamma radiolysis $\left(1.19 \mathrm{~Gy} \mathrm{~s}^{-1}\right)$ of $2 \mathrm{mM}$ americium in aerated $3.0 \mathrm{M} \mathrm{HNO}_{3}$. Arrows indicate the change in absorption peak growth or decay.

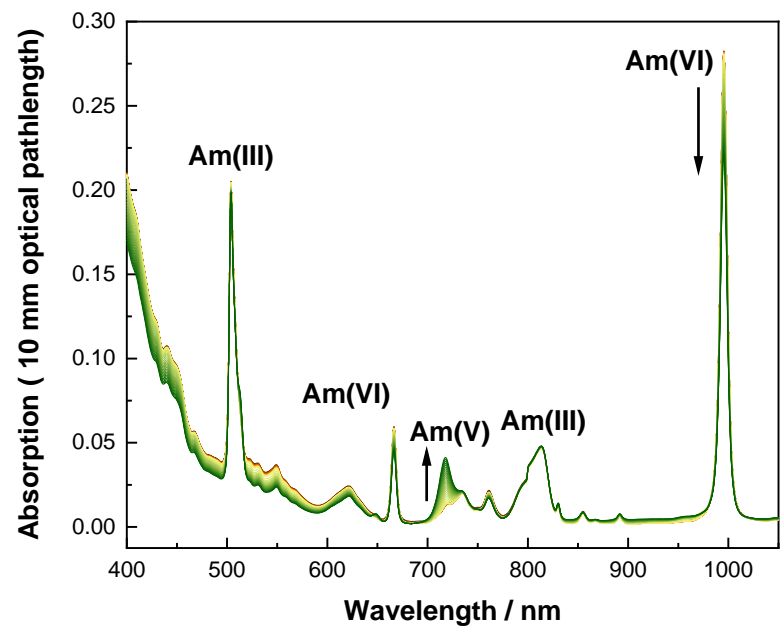

Figure S2. Complimentary UV-Vis absorption spectra for manuscript Figure 3 - alpha selfradiolysis $\left(7.47 \times 10^{-3} \mathrm{~Gy} \mathrm{~s}^{-1}\right)$ of $4 \mathrm{mM}$ americium in aerated 3.0 $\mathrm{M} \mathrm{HNO}_{3}$. Arrows indicate the change in absorption peak growth or decay. 


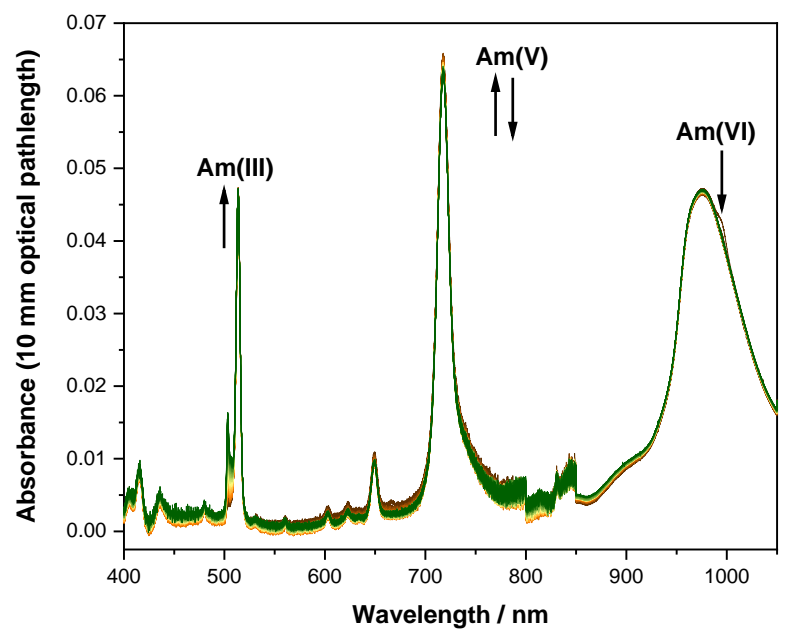

Figure S3. Complimentary UV-Vis absorption spectra for manuscript Figure 4 - alpha selfradiolysis $\left(2.37 \times 10^{-3} \mathrm{~Gy} \mathrm{~s}^{-1}\right)$ of $1.39 \mathrm{mM}$ americium in aerated $1.0 \mathrm{M} \mathrm{HNO}_{3}$. Arrows highlight Am(VI) shoulder peak and its decay, and the change in absorption peak growth or decay of Am(III) and $\mathrm{Am}(\mathrm{VI})$.

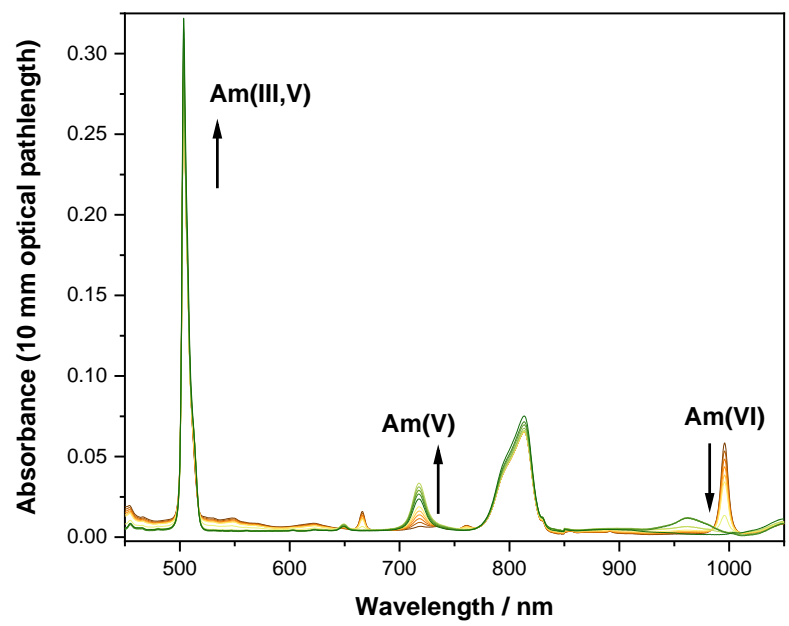

Figure S4. Complimentary UV-Vis absorption spectra for Figure S9 - gamma radiolysis $\left(1.15 \mathrm{~Gy} \mathrm{~s}^{-1}\right)$ of $2 \mathrm{mM}$ americium in aerated $1.0 \mathrm{M} \mathrm{HNO}_{3}$. Arrows indicate the change in absorption peak growth or decay. 


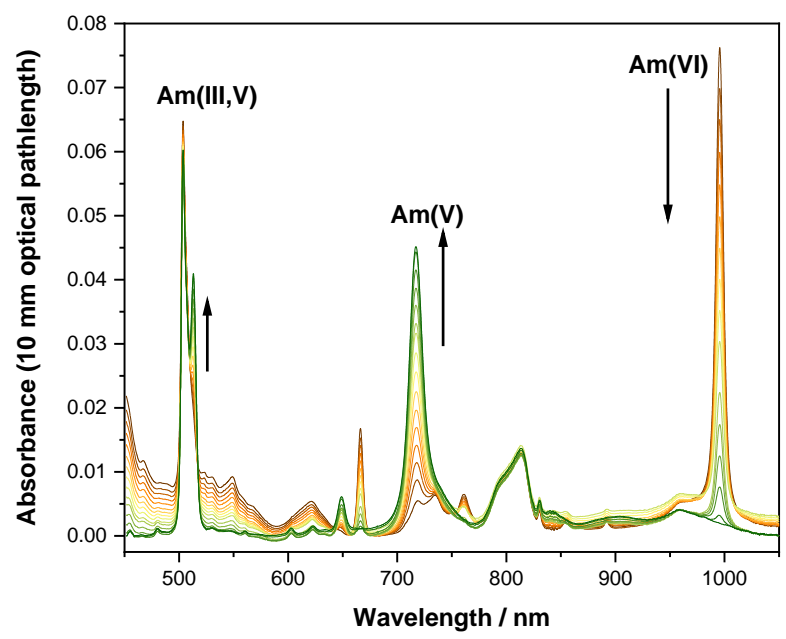

Figure S5. Complimentary UV-Vis absorption spectra for Figure S10 - gamma radiolysis $\left(1.14 \mathrm{~Gy} \mathrm{~s}^{-1}\right)$ of $1 \mathrm{mM}$ americium in aerated $3.0 \mathrm{M} \mathrm{HNO}_{3}$. Arrows indicate the change in absorption peak growth or decay.

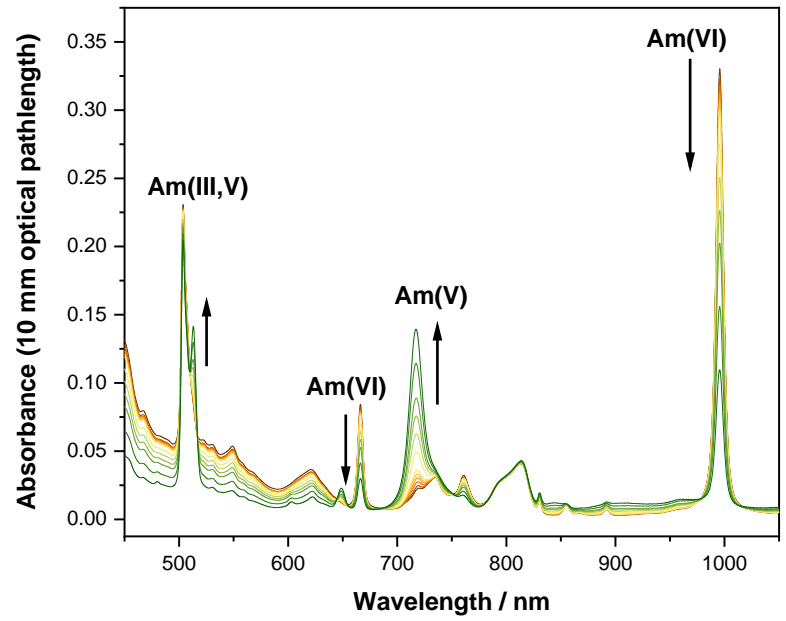

Figure S6. Complimentary UV-Vis absorption spectra for Figure S11 - gamma radiolysis $\left(1.15 \mathrm{~Gy} \mathrm{~s}^{-1}\right)$ of $4 \mathrm{mM}$ americium in aerated 3.0 $\mathrm{M} \mathrm{HNO}_{3}$. Arrows indicate the change in absorption peak growth or decay. 


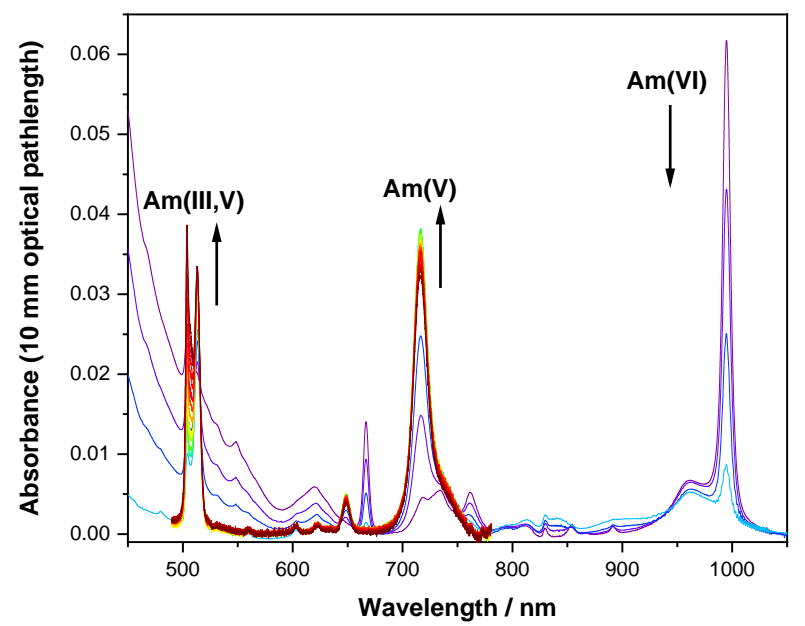

Figure S7. Complimentary UV-Vis absorption spectra for Figure S12 - gamma radiolysis $\left(0.93 \mathrm{~Gy} \mathrm{~s}^{-1}\right)$ of $1 \mathrm{mM}$ americium in aerated $6.5 \mathrm{M} \mathrm{HNO}_{3}$. Arrows indicate the change in absorption peak growth or decay. A higher resolution scan rate was used for the irradiation of $\mathrm{Am}(\mathrm{V})$ and subsequent reduction. The initial scans with the larger wavelength window were made only to verify the reduction of Am(VI) induced by gamma irradiation.

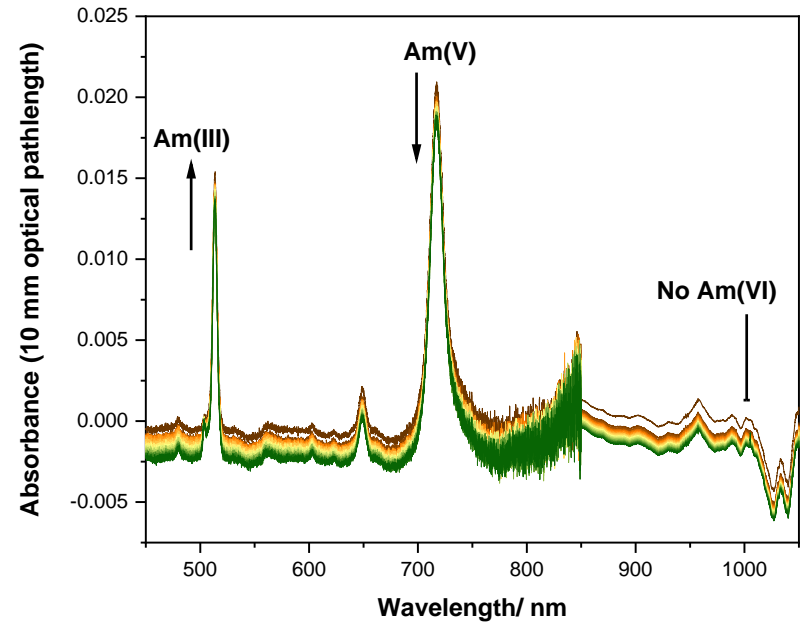

Figure S8. Complimentary UV-Vis absorption spectra for Figure S13 - alpha self-radiolysis $\left(9.09 \times 10^{-4} \mathrm{~Gy} \mathrm{~s}^{-1}\right)$ of $0.48 \mathrm{mM}$ americium in aerated $3.0 \mathrm{M} \mathrm{HNO}_{3}$. Arrows highlight absence of an Am(VI) peak and the change in absorption peak growth and decay of Am(III) and Am(V). 


\section{Gamma Irradiations}
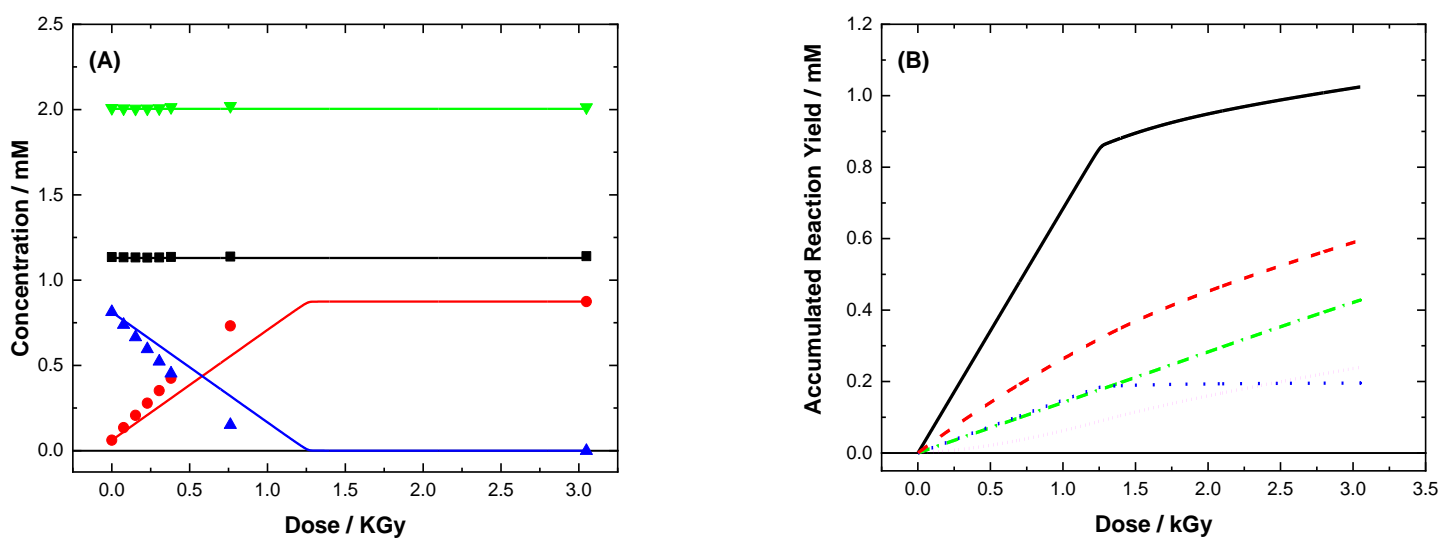

Figure S9. (A) Concentration of $\mathrm{Am}(\mathrm{III})(\mathbf{\nabla}), \mathrm{Am}(\mathrm{V})(\bullet), \mathrm{Am}(\mathrm{VI})(\mathbf{\Delta})$, and Am mass balance $(\nabla)$ as a function of absorbed dose for the gamma radiolysis $\left(1.19 \mathrm{~Gy} \mathrm{~s}^{-1}\right)$ of $2 \mathrm{mM}$ americium in aerated 1.0 $\mathrm{M} \mathrm{HNO}_{3}$. Complementary absorption spectra are shown in Figure S4. Solid lines are predicted values from multi-scale modelling calculations. (B) Calculated accumulated americium reaction kinetics: $\mathrm{Am}(\mathrm{VI})+\mathrm{HNO}_{2}$ (Solid Black), $\mathrm{Am}(\mathrm{VI})+\mathrm{H}_{2} \mathrm{O}_{2}$ (Dashed Red), $\mathrm{Am}(\mathrm{VI})+\mathrm{HO}_{2}{ }^{\circ}$ (Dotted Blue), Am(V) $+{ }^{\circ} \mathrm{NO}_{3}$ (Dot-Dash Green), and Am(V) + ${ }^{\circ} \mathrm{OH}$ (Short-Dotted Magenta).
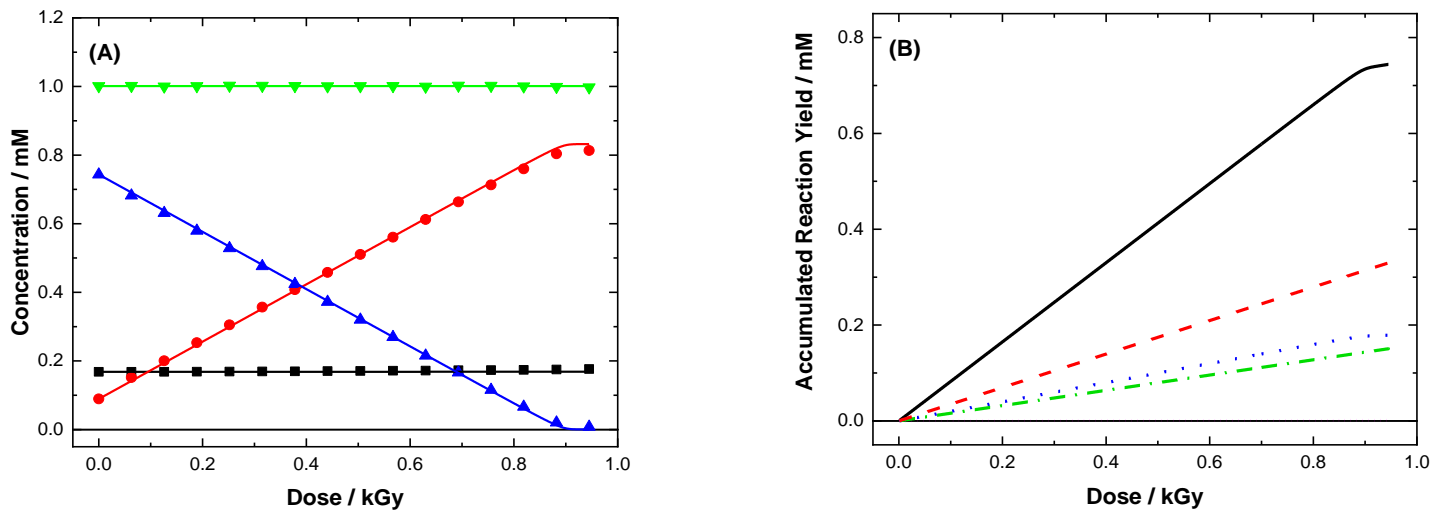

Figure S10. (A) Concentration of $\operatorname{Am}(\mathrm{III})(\boldsymbol{\nabla}), \operatorname{Am}(\mathrm{V})(\bullet), \operatorname{Am}(\mathrm{VI})(\mathbf{\Delta})$, and Am mass balance $(\nabla)$ as a function of absorbed dose for the gamma radiolysis $\left(1.14 \mathrm{~Gy} \mathrm{~s}^{-1}\right)$ of $1 \mathrm{mM}$ americium in aerated 3.0 $\mathrm{M} \mathrm{HNO}_{3}$. Complementary absorption spectra are shown in Figure S5. Solid lines are predicted values from multi-scale modelling calculations. (B) Calculated accumulated americium reaction kinetics: Am(VI) $+\mathrm{HNO}_{2}$ (Solid Black), $\mathrm{Am}(\mathrm{VI})+\mathrm{H}_{2} \mathrm{O}_{2}$ (Dashed Red), $\mathrm{Am}(\mathrm{VI})+\mathrm{HO}_{2}{ }^{\circ}$ (Dotted Blue), Am(V) $+{ }^{\circ} \mathrm{NO}_{3}$ (Dot-Dash Green), and Am(V) + ${ }^{\circ} \mathrm{OH}$ (Short-Dotted Magenta). 

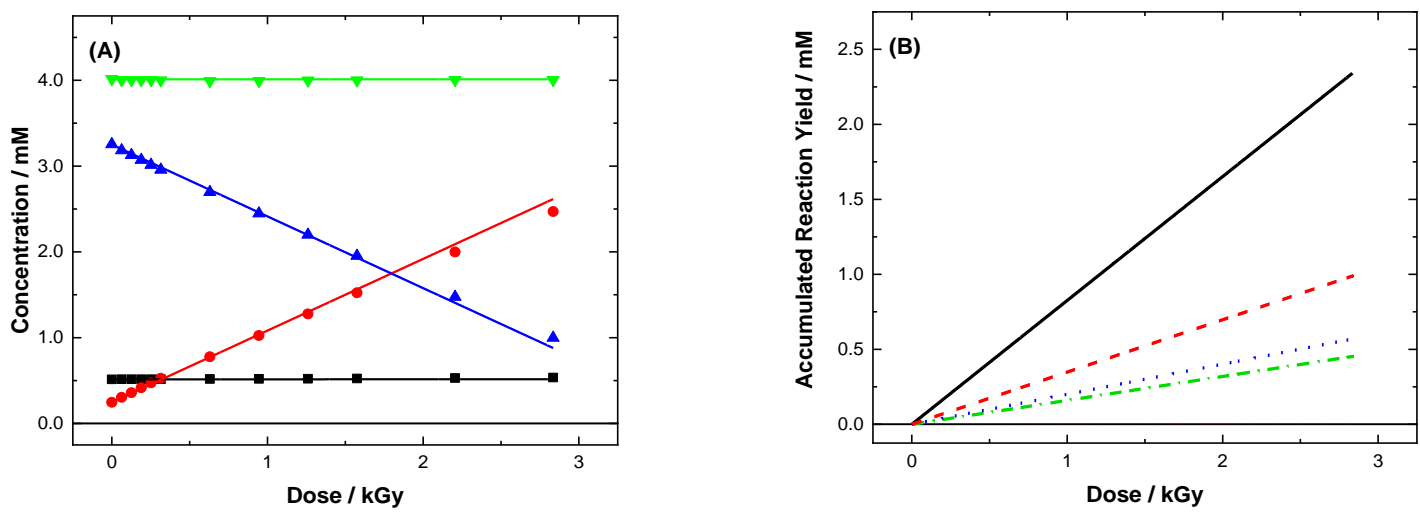

Figure S11. (A) Concentration of $\mathrm{Am}(\mathrm{III})(\boldsymbol{\square}), \mathrm{Am}(\mathrm{V})(\bullet), \mathrm{Am}(\mathrm{VI})(\mathbf{\Delta})$ and Am mass balance $(\nabla)$ as a function of absorbed dose for the gamma radiolysis $\left(1.15 \mathrm{~Gy} \mathrm{~s}^{-1}\right)$ of $4 \mathrm{mM}$ americium in aerated 3.0 $\mathrm{M} \mathrm{HNO}_{3}$. Complementary absorption spectra are shown in Figure S6. Solid curves are predicted values from multi-scale modelling calculations. (B) Calculated accumulated americium reaction kinetics: $\mathrm{Am}(\mathrm{VI})+\mathrm{HNO}_{2}$ (Solid Black), $\mathrm{Am}(\mathrm{VI})+\mathrm{H}_{2} \mathrm{O}_{2}$ (Dashed Red), $\mathrm{Am}(\mathrm{VI})+\mathrm{HO}_{2}{ }^{\circ}$ (Dotted Blue), Am(V) $+{ }^{\circ} \mathrm{NO}_{3}$ (Dot-Dash Green), and Am(V) + ${ }^{\circ} \mathrm{OH}$ (Short-Dotted Magenta).
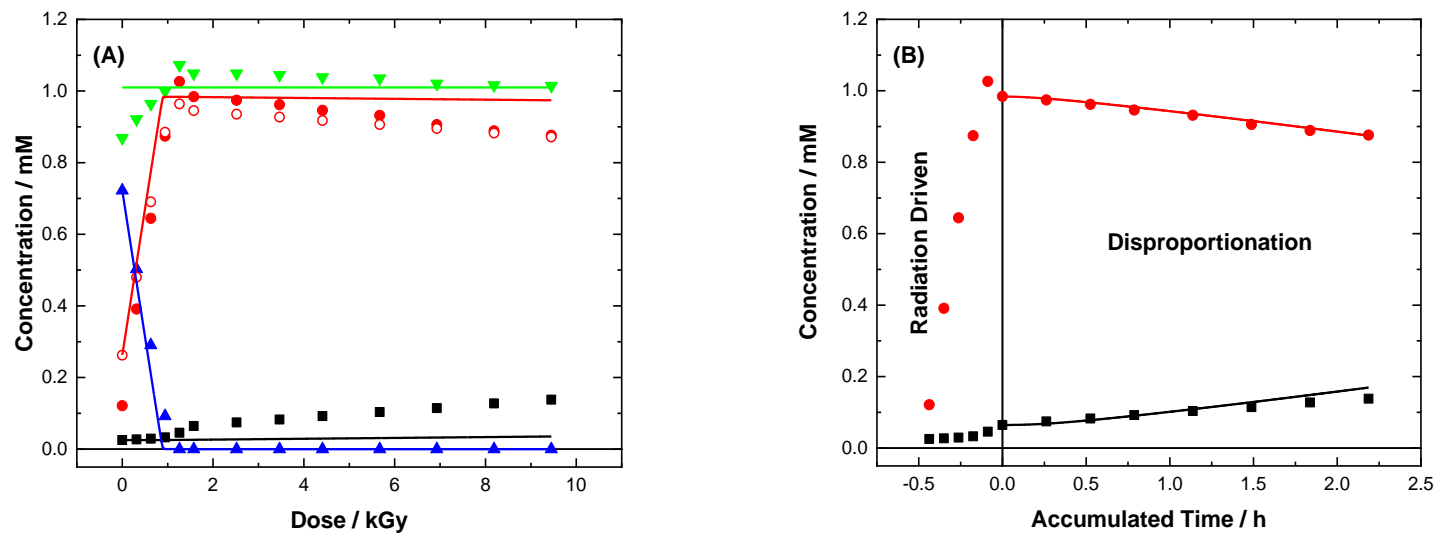

Figure S12. (A) Concentration of $A m(I I I)(\boldsymbol{\square}), A m(V)(\bullet)$, corrected Am(V) (O), Am(VI) (A), and Am mass balance $(\nabla)$ as a function of absorbed dose for the gamma radiolysis $\left(0.93 \mathrm{~Gy} \mathrm{~s}^{-1}\right)$ of $1 \mathrm{mM}$ americium in aerated $6.5 \mathrm{M} \mathrm{HNO}_{3}$. Complementary absorption spectra are shown in Figure S7. (B) Concentration of Am(III) (ם) and Am(V) (•) as a function of time to highlight the transition from radiolytically driven processes to disproportionation. Solid lines in both figures are predicted values from multi-scale modelling calculations. 


\section{Alpha Self-Radiolysis Irradiations}
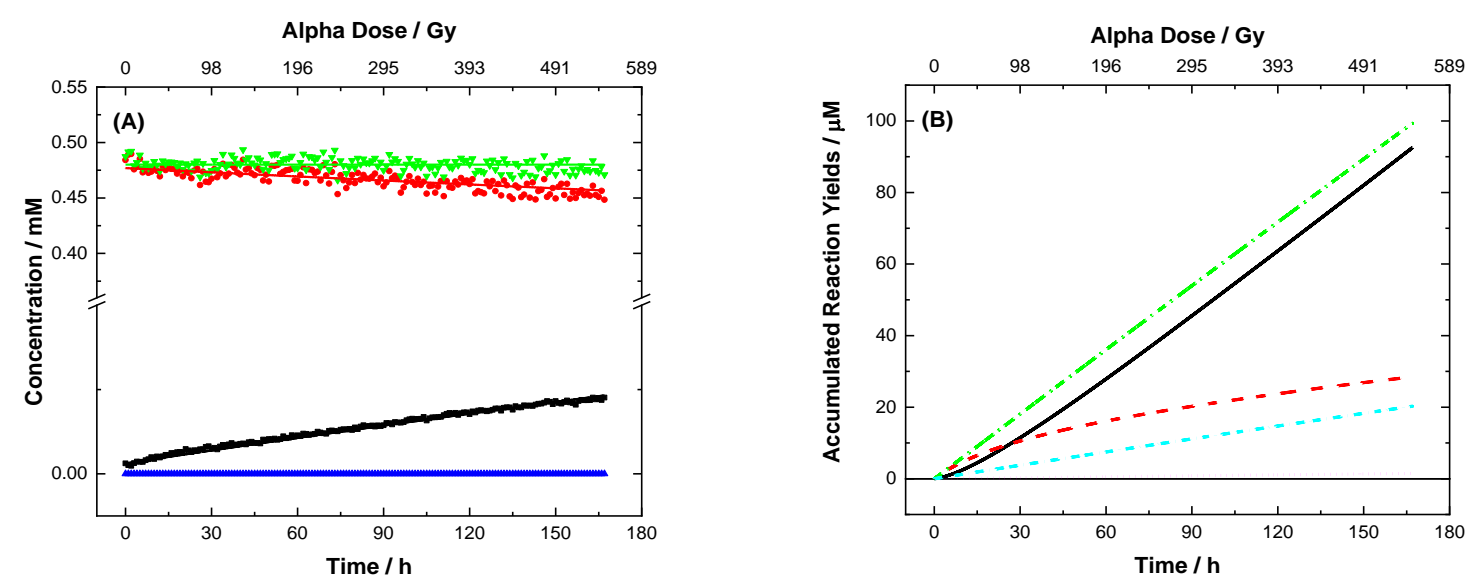

Figure S13. (A) Concentration of $\operatorname{Am}(\mathrm{III})(\boldsymbol{\nabla}), \operatorname{Am}(\mathrm{V})(\bullet), \operatorname{Am}(\mathrm{VI})(\mathbf{\Delta})$, and Am mass balance $(\nabla)$ as a function of time for the alpha self-radiolysis $\left(9.09 \times 10^{-4} \mathrm{~Gy} \mathrm{~s}^{-1}\right)$ of $0.48 \mathrm{mM}$ americium in aerated 3.0 $\mathrm{M} \mathrm{HNO}_{3}$. Complementary absorption spectra are shown in Figure S8. Solid lines are predicted values from multi-scale modelling calculations. (B) Calculated accumulated americium reaction kinetics: $\mathrm{Am}(\mathrm{VI})+\mathrm{HNO}_{2}$ (Black Solid), $\mathrm{Am}(\mathrm{VI})+\mathrm{H}_{2} \mathrm{O}_{2}$ (Dashed Red), $\mathrm{Am}(\mathrm{V})+\mathrm{NO}_{3}$ (Dot-Dash Green), $\mathrm{Am}(\mathrm{V})+{ }^{\circ} \mathrm{OH}$ (Short-Dotted Magenta), and Am(V) disproportionation (Short-Dash-Dot Cyan). 